\title{
Research Article \\ Effects of Population Density and Nitrogen Rate in Ultra Narrow Row Cotton
}

\author{
William T. Molin ${ }^{1}$ and Josie A. Hugie ${ }^{2}$ \\ ${ }^{1}$ Southern Weed Science Research Unit, USDA-ARS, Stoneville, MS 38776, USA \\ ${ }^{2}$ Syngenta Crop Protection, 410 Swing Rd, Greensboro, NC 27409, USA \\ Correspondence should be addressed to William T. Molin, william.molin@ars.usda.gov
}

Received 30 July 2009; Accepted 2 September 2009

Copyright (C) 2010 W. T. Molin and J. A. Hugie. This is an open access article distributed under the Creative Commons Attribution License, which permits unrestricted use, distribution, and reproduction in any medium, provided the original work is properly cited.

\begin{abstract}
A field study was conducted to investigate the effects of population density and nitrogen rate on yield, growth, and fiber response of ultra narrow row (UNR) cotton. Stand loss occurred at densities greater than 22 plants $\mathrm{m}^{-2}$ and nitrogen rates greater than $56 \mathrm{~kg} \mathrm{ha}^{-1}$ and stand loss exceeded $20 \%$ at harvest. Seed cotton yields were similar across populations and rates of 56, 112, and $168 \mathrm{~kg} \mathrm{ha}^{-1}$. Nitrogen rates greater than $56 \mathrm{~kg} \mathrm{ha}^{-1}$ resulted in greater vegetative growth based on increased plant height and number of nodes. These results indicate that populations of 22 plants $\mathrm{m}^{-2}$ and nitrogen rates of $56 \mathrm{~kg} \mathrm{ha}^{-1}$ were sufficient for maximum yields in UNR cotton under our conditions. However, at higher nitrogen rates, boll formation increased at lower nodes with no corresponding change in yield. Higher nitrogen rates may promote earliness and distribute yield across more fruiting sites.
\end{abstract}

\section{Introduction}

Ultra narrow row (UNR) cotton production has been proposed as an economical means to increase cotton production efficiency (Atwell et al. [1], McFarland et al. [2]). Advantages of a UNR production system include earlier crop development, reduced costs from late season insect control, and in some cases, increased yields ( McFarland et al. [2]). Concerns regarding management of rank growth and weed control in ultra narrow rows have been abated by development of plant growth regulators and herbicide resistant cultivars (Atwell et al. [1], Reeves et al. [3]). Advances in planter technology allowing precise seed singulation and placement and improving finger strippers for harvest have led to improved stand establishment and harvest efficiency. As a result, interest in UNR production has increased in recent years. Unfortunately, the yield advantages of UNR cotton have been inconclusive. UNR yields were equal to or exceeded wide row (WR) yields in some cases (Bader et al. [4], Cawley et al. [5], Gwathmey et al. [6], Jost and Cothren [7, 8], Reeves et al. [3], and Wiatrak et al. [9]) whereas no yield advantage was reported by others (Bednarz et al. [10], Boquet et al. [11], Boquet [12], Clawsen et al. [13], Jones et al. [14], Rinehardt et al. [15]). The uncertainty of a yield advantage of UNR cotton has led to research on identifying appropriate nitrogen rates and population densities to improve yields.

Nitrogen management is an important aspect of UNR cotton production because excessive nitrogen may lead to rank growth and defoliation difficulties whereas insufficient nitrogen may decrease yields (Rinehardt et al. [15]). Several studies have shown little or no increase in UNR cotton yield in response to nitrogen (Boquet et al. [11]; Boquet [12]; Marois et al. [16]; Rinehardt et al. [15]; Wright et al. [17]). Studies in which yield responses to nitrogen were detected have not clearly defined a minimum nitrogen rate. McConnell et al. [18] reported that fertilization with more than $56 \mathrm{~kg} \mathrm{ha}^{-1}$ did not significantly yield. Howard et al. [19] reported lint yield increased incrementally from 0 to $101 \mathrm{~kg} \mathrm{ha}^{-1}$ nitrogen per acre although no further increases were found at higher rates. Clawson et al. [13] found a significant increase in lint yield with each $50 \mathrm{~kg} \mathrm{ha}^{-1}$ increase in nitrogen from 0 to $151 \mathrm{~kg} \mathrm{ha}^{-1}$ although the magnitude of the increase was less with each additional increment of nitrogen (Clawson et al. [13]). The fields were depleted of nitrogen in the year prior to initiation of the study by producing grain sorghum in the test field. The nitrogen requirements for UNR cotton were not lower than WR 
cotton (Clawson et al. [13]). The inconsistent responses of UNR cotton to changes in nitrogen rate for UNR cotton indicate that specific nitrogen rate recommendations need to be more precisely defined.

Selection of a population density sufficient to produce an even canopy has also received attention in UNR research. Atwell et al. [1] proposed UNR cotton populations of 210000 to 378000 plants $\mathrm{ha}^{-1}$ in row widths of 19 to $25 \mathrm{~cm}$. These populations are 2 - to 3 -fold higher than in wide row cotton where populations of 50000 to 150000 plants ha $^{-1}$ in row widths of 76 to $100 \mathrm{~cm}$ are used (Marois et al. [16]). UNR cotton yields were similar over a 2- to 3-fold range in plant populations from 120000 to 450000 plants ha hadicating $^{-1}$ ind that lower populations were acceptable (Allen et al. [20], Jones et al. [14], Jost and Cothren [8]), and producers could reduce seed costs without compromising yield (Boquet [12]). Allen et al. [20] reported that, in one study, the highest yields came from plots with the lowest population. Thus, determination of the minimum population necessary to achieve the highest yields is important in order to reduce costs of UNR production, especially when high seedling rates with more costly transgenic seed is required.

Few studies have examined the interaction between population densities and nitrogen rate in UNR cotton. Boquet et al. [11] found no effect of plant density or nitrogen rate on yield. Boquet [12] found a significant nitrogen rate by plant population interaction, and showed that increased plant population decreased yield.

The objective of this research was to examine the effects of population densities and nitrogen rates on seed cotton yields and plant architecture in UNR cotton in order to determine the most cost effective management strategies in the Mid-South.

\section{Materials and Methods}

2.1. Field Preparation and Treatments. Research was conducted from 2000 to 2002 at the USDA-ARS Southern Weed Science Research Farm, Stoneville, MS ( $33^{\circ} \mathrm{N}$ latitude) on a Bosket silt loam (fine-silty, mixed thermic Aeric Ochraqualf). The soil had a pH 6.7, 1\% organic matter, a CEC of $15 \mathrm{me} / 100 \mathrm{~g}$, and soil textural fractions of $26 \%$ sand, $56 \%$ silt, and $18 \%$ clay. Field preparation in the fall consisted of disking, subsoiling, and bedding. In the spring, beds were reduced to approximately $8 \mathrm{~cm}$ with a reel and harrow conditioner. These low beds were suitable for irrigation and planting. In the year prior to test initiation, the test area was planted in UNR cotton but not fertilized to deplete soil nitrogen. Nitrogen rate recommendations based on soil analyses on this field (Pettiet Agricultural Services, Leland, MS) were $134 \mathrm{~kg} \mathrm{Nha}^{-1}$. Test plots were $13 \mathrm{~m} \mathrm{long}$ and $4 \mathrm{~m}$ wide which allowed 16 rows spaced $25 \mathrm{~cm}$ apart.

Fertilizer application and insect control programs were standard for cotton production (Reddy [21]). Potash, phosphorus, and sulfur (134: $34: 5.6 \mathrm{~kg} \mathrm{ha}^{-1}$ ) were applied with a commercial granular applicator in the fall. Nitrogen was applied as prilled ammonium nitrate (34-0-0) at 0,56 , 112 , and $168 \mathrm{~kg} \mathrm{ha}^{-1}$ using a rotary spreader to plots three to four days after planting. Cotton was furrow irrigated on
July 28, 2000; July 12 and 24, 2001; and June 4 and 22, and August 14, 2002. Cotton cultivar Delta and Pine Land " 422 BR" was planted on May 11, 2000; April 26, 2001; and May 20, 2002 at 222000, 296000, 370000, or 444000 seeds ha ${ }^{-1}$ using a Monosem NG Plus precision planter.

Herbicide and growth regulator treatments were applied with a tractor-mounted sprayer with fan nozzles delivering $187 \mathrm{~L} \mathrm{ha}^{-1}$ water at $179 \mathrm{kPa}$. Weed control consisted of paraquat $\left(1.1 \mathrm{~kg} \mathrm{aiha}^{-1}\right)$ applied preplant, followed by fluometuron and pendimethalin (1.1 and $\left.0.8 \mathrm{~kg} \mathrm{ha}^{-1}\right)$ at planting, followed by glyphosate $\left(1.1 \mathrm{~kg}\right.$ ai ha $\left.{ }^{-1}\right)$ at the one and four-leaf stages of cotton growth. Subsequent weed control was accomplished by hoeing. Plant height was managed with mepiquat chloride $\left(30.7 \mathrm{~g}\right.$ ai ha $\left.{ }^{-1}\right)$ applied at first matchhead square and two weeks thereafter. Harvest preparation consisted of defoliation by two applications of thidiazuron and diuron at $1 \mathrm{kgaiha}^{-1}$ and $0.5 \mathrm{kgai} \mathrm{ha}^{-1}$, respectively, followed by boll opening with ethephon at $1.1 \mathrm{~kg}$ ai ha ${ }^{-1}$.

2.2. Data Collection. Field plots were harvested with a John Deere 1755 Finger stripper harvested modified with a bagging attachment to determine seed cotton yields, lint percentage, and lint yield. Burrs, leaves, and stalks were removed by hand prior to weighing. Boll counts, boll weight, bolls per plant, stand counts, and height and nodes were determined by hand picking a $2 \mathrm{~m}^{2}$ plot perpendicular to the direction of planting on the center eight rows. Seed cotton was ginned with a Continental Eagle laboratory gin, and fiber properties were determined by the USDAAgricultural Marketing Service, Dumas, AR. Plant height and node measurements and bolls by node position were taken on ten randomly selected plants per plot.

2.3. Statistical Methods. The experimental design for each year was a randomized complete block with factorial treatment structure of four plant populations and four nitrogen rates with four replications and repeated for three years. Nitrogen treatments were reapplied in the same plot and populations were randomly reassigned to nitrogen plots. Therefore, in an analysis combined over years the experimental design is a split plot where nitrogen is the main unit and population is a subunit. The design changes to a split plot because year is a repeated measure for the nitrogen main unit treatment and an additional level of replication for the population subunit treatment. Data were subjected to analysis of variance in PROC MIXED (Statistical Analysis Systems, 2005, Software version 9.1., Cary, NC) to determine the significance among main effects. Treatments were separated at the $5 \%$ level of significance using an LSD test.

For traits in which there was a significant interaction between year and population density or nitrogen rate, the results were presented by year. In cases where the year by population density, year by nitrogen rate, or population density by nitrogen rate interactions were not significant, data were averaged across years, population densities were 
TABLE 1: Effect of plant population and nitrogen rate on the stand count as a percentage of the target population at harvest averaged over three years.

\begin{tabular}{lcccc}
\hline & \multicolumn{4}{c}{$\begin{array}{c}\text { Population density (\% of target population) } \\
\left.\text { Target population density (plants } \mathrm{m}^{-2}\right)\end{array}$} \\
\hline $\begin{array}{l}\text { Nitrogen } \\
\left(\mathrm{kg} \mathrm{ha}^{-1}\right)\end{array}$ & 22 & 30 & 37 & 44 \\
0 & 95.0 & 87.6 & 86.7 & 84.0 \\
56 & 98.9 & 86.9 & 82.9 & 78.4 \\
112 & 92.9 & 85.4 & 74.0 & 73.0 \\
168 & 93.3 & 86.0 & 79.4 & 74.3 \\
\hline
\end{tabular}

The LSD for comparing stand count as a percentage of the target population (same nitrogen rate) at harvest is 5.4. The LSD for comparing nitrogen rate (same target population) at harvest is 5.0.

averaged across nitrogen rates, and nitrogen rates were averaged across population densities.

\section{Results and Discussion}

Population densities determined at 3 weeks after planting indicated the initial densities were within $90 \%$ of the target populations, and there were no differences in population densities across nitrogen rates (data not shown). Population densities determined at harvest were within $90 \%$ of the target population for all nitrogen rates for the target population of 22 (Table 1). Population density percentages dropped to approximately $86 \%$ across all nitrogen rates at a target population of 30 . The trend in plant mortality was also observed at target populations of 37 and 44 where population density percentages dropped from $87 \%$ to $79 \%$, and from $84 \%$ to $74 \%$, as nitrogen rate increased from 0 to $168 \mathrm{~kg} \mathrm{ha}^{-1}$, respectively.

Jost and Cothren [8] observed a decrease in stand from 40 seeds $\mathrm{m}^{-2}$, the stand established at thinning, to 35 seeds $\mathrm{m}^{-2}$, at harvest, in one year of a two-year study. The stand loss, which prompted stand counts, may have been caused by insect or disease pressure or natural plant mortality. However, Clawson et al. [13] and Wiatrak et al. [9] reported that final plant populations were not affected by nitrogen rate.

The reduced stands at the higher populations may have resulted from intraplant competition. Molin et al. [22] reported that UNR cotton population densities at 31 plants $\mathrm{ha}^{-1}$ decreased as the spurred anoda density increased although population densities in conventionallyspaced cotton did not decrease under the same weed pressure. Overall, the results indicate that nitrogen rates and population densities need not exceed $56 \mathrm{~kg} \mathrm{ha}^{-1}$ or 22 plants $\mathrm{m}^{-2}$, respectively, to achieve a stable population density at harvest.

There were no significant differences in seed cotton yield, lint percentage, and lint yield between population densities (Table 2). Larson et al. [23] found that yields were consistent across populations for populations greater than 9 plants $\mathrm{m}^{-2}$ and suggested using population densities as low as 15 plants $\mathrm{m}^{-2}$. In contrast, Boquet [12] reported a decrease in yield with increasing plant density, and Gerik et al. [24] reported a yield increase with increasing plant density. Several studies have indicated that population densities need not exceed those for wide-row cotton (Boquet [12], Jones et al. [14]; Jost and Cothren [7]). Although the lowest population density used was 22 plants $\mathrm{m}^{-2}$, the trend of lower populations delivering comparable yields to high densities was observed.

Boll numbers (bolls $\mathrm{m}^{-2}$ ) and boll weight were not significantly different across populations (Table 2). Bolls plant $^{-1}$ decreased from 3.7 to 2.4 plant $^{-1}$ as the target population density increased from 22 to 44 plants $\mathrm{m}^{-2}$ (Table 2). These results demonstrate that boll production was consistent per unit area regardless of population density and argue against using the higher densities.

Seed cotton yields, bolls plant ${ }^{-1}$, boll weight, and bolls $\mathrm{m}^{-2}$ increased as nitrogen rate increased from 0 to $56 \mathrm{~kg} \mathrm{ha}^{-1}$, but there were no further increases at rates greater than $56 \mathrm{~kg} \mathrm{ha}^{-1}$. These results are consistent with those of Clawson et al. [13] and Howard et al. [19] who showed incremental increases in yields with added nitrogen. The lint yield at $0 \mathrm{~kg} \mathrm{ha}^{-1}$ nitrogen was $660 \mathrm{~kg} \mathrm{ha}^{-1}$, and Clawson et al. [13] and Howard et al. [19] reported lint yields at 0 nitrogen of $805 \mathrm{lb}$ lint per acre and $827 \mathrm{~kg} \mathrm{ha}^{-1}$, respectively. These results indicate that there was sufficient residual nitrogen to support some lint production in each of these studies. The yields by year at $0 \mathrm{~kg} \mathrm{ha}^{-1}$ nitrogen were 854, 634, and $492 \mathrm{~kg} \mathrm{ha}^{-1}$ in 2000, 2001, and 2002, respectively, indicating a continual yield decrease. Studies performed in fields where nitrogen levels are not depleted may result in nitrogen rate recommendations that exceed the production needs of the crop.

Plant height increased in response to increase in nitrogen rate, but the population density effect on height was not significant (Table 3). Marois et al. [16] also reported a significant increase in plant height in UNR cotton as well as increases in nodes and height to node ratio of the magnitude reported here. In contrast, Boquet [12] and Jost and Cothren [7] reported that plant height was not affected by plant density, and Boquet [12] also saw no affect of nitrogen rate on plant height.

Nodes decreased in response to increases in population density but increased in response to increasing nitrogen. The difference in height and nodes between 56 and $168 \mathrm{~kg} \mathrm{ha}^{-1}$ nitrogen was approximately $18 \mathrm{~cm}$ and 2 nodes, respectively, with no yield advantage between these rates.

There were no significant differences between population densities for percentage bolls by node position. The mean percentages were 23,41 , and 39 for nodes 4 to 8 , and 9 to 12 , and greater than 12, respectively. Jost and Cothren [7] reported a percentage of bolls of UNR cotton for nodes 6 through 10 to be 76 averaged across three populations. In contrast, for nodes 4 through 12, the percentage of bolls was 64 which show that greater than half of boll production was confined to the lower positions.

The percentage of bolls for nodes 4 to 8 increased with nitrogen rate to $112 \mathrm{~kg} \mathrm{ha}^{-1}$ (Table 4 ). The percentage 
TABLE 2: Effect of plant population density and nitrogen rate on seed cotton yield, lint percentage, lint yield, bolls plant ${ }^{-1}$, bolls number, and boll weight averaged over years.

\begin{tabular}{|c|c|c|c|c|c|c|}
\hline Treatments & $\begin{array}{l}\text { Seed cotton yield } \\
\left(\mathrm{kg} \mathrm{ha}^{-1}\right)\end{array}$ & Lint (\%) & $\begin{array}{c}\text { Lint Yield } \\
\left(\mathrm{kg} \mathrm{ha}^{-1}\right)\end{array}$ & Bolls Plant ${ }^{-1}$ & $\begin{array}{c}\text { Boll number } \\
\left(\text { boll } \mathrm{m}^{-2}\right)\end{array}$ & $\begin{array}{c}\text { Boll weigh } \\
(\mathrm{g})\end{array}$ \\
\hline \multicolumn{7}{|c|}{$\begin{array}{l}\text { Target Population } \\
\left(\text { plant } \mathrm{m}^{-2}\right)\end{array}$} \\
\hline 22 & 2695 & 37.9 & 1015 & 3.7 & 81.1 & 3.4 \\
\hline 30 & 2634 & 37.6 & 981 & 3.2 & 81.0 & 3.3 \\
\hline 37 & 2586 & 37.5 & 963 & 2.9 & 83.3 & 3.1 \\
\hline 44 & 2590 & 38.3 & 985 & 2.4 & 81.3 & 3.3 \\
\hline $\operatorname{LSD}(P=.05)$ & ns & ns & ns & 0.2 & ns & ns \\
\hline$P>F$ & .55 & .35 & .97 & .01 & .77 & .16 \\
\hline \multicolumn{7}{|c|}{ Nitrogen $\left(\mathrm{kg} \mathrm{ha}^{-1}\right)$} \\
\hline 0 & 1736 & 38.7 & 661 & 2.1 & 59.3 & 3.0 \\
\hline 56 & 2991 & 38.2 & 1133 & 3.2 & 89.8 & 3.4 \\
\hline 112 & 2921 & 37.2 & 1087 & 3.4 & 88.4 & 3.4 \\
\hline 168 & 2859 & 37.2 & 1066 & 3.4 & 89.1 & 3.2 \\
\hline $\operatorname{LSD}(P=.05)$ & 184 & 1.0 & 97 & 0.2 & 5.1 & 0.3 \\
\hline$P>F$ & .01 & .01 & .01 & .01 & .01 & .03 \\
\hline
\end{tabular}

TABLE 3: Effect of plant population density and nitrogen rate on height for each year and number of nodes at harvest averaged over years.

\begin{tabular}{|c|c|c|c|c|}
\hline \multirow[b]{2}{*}{ Treatments } & \multicolumn{3}{|c|}{ Height $(\mathrm{cm})$} & \multirow[t]{2}{*}{ Nodes } \\
\hline & 2000 & 2001 & 2002 & \\
\hline \multicolumn{5}{|c|}{$\begin{array}{l}\text { Target population } \\
\left(\text { plant } \mathrm{m}^{-2} \text { ) }\right.\end{array}$} \\
\hline 22 & 77.3 & 64.2 & 69.7 & 16.5 \\
\hline 30 & 75.1 & 59.4 & 70.0 & 16.1 \\
\hline 37 & 77.1 & 63.8 & 69.6 & 15.9 \\
\hline 44 & 77.1 & 62.1 & 68.8 & 15.5 \\
\hline $\operatorname{LSD}(P=.05)$ & ns & $\mathrm{ns}$ & $\mathrm{ns}$ & 0.6 \\
\hline$P>F$ & .44 & .40 & .95 & .01 \\
\hline \multicolumn{5}{|c|}{ Nitrogen $\left(\mathrm{kg} \mathrm{ha}^{-1}\right)$} \\
\hline 0 & 56.8 & 41.5 & 44.7 & 13.9 \\
\hline 56 & 73.6 & 59.0 & 65.4 & 15.8 \\
\hline 112 & 83.6 & 73.0 & 80.8 & 16.9 \\
\hline 168 & 92.5 & 76.0 & 87.3 & 17.8 \\
\hline $\operatorname{LSD}(P=.05)$ & 3.1 & 4.1 & 4.3 & 0.6 \\
\hline$P>F$ & .01 & .01 & .01 & .01 \\
\hline
\end{tabular}

of bolls at $56 \mathrm{~kg} \mathrm{ha}^{-1}$ nitrogen was significantly less than at $112 \mathrm{~kg} \mathrm{ha}^{-1}$ nitrogen. This is surprising considering the yield data which showed equivalent yields between 56 and $168 \mathrm{~kg} \mathrm{ha}^{-1}$ nitrogen. The percentages of bolls for nodes 9 to 12 were relatively constant for all nitrogen rates with the exception for $0 \mathrm{~kg} \mathrm{ha}^{-1}$ nitrogen in 2001 and 2002 . These results indicate that nitrogen was sufficient for boll development at all nitrogen rates. At nodes greater than 12, the percentages of bolls were greater at 0 and $56 \mathrm{~kg} \mathrm{ha}^{-1}$ nitrogen than at higher nitrogen rates. High nitrogen rates may have reduced boll numbers at positions 4 through 8 because of shading or excessive growth.

Micronaire, fiber length, strength, and uniformity were not affected by increasing population density (Table 5). 
TABLE 4: Effect of plant population density and nitrogen rate on percentage of bolls found at nodes 4 through 8,9 through 12 , and greater than 12 .

\begin{tabular}{|c|c|c|c|c|c|c|c|c|c|}
\hline \multirow{3}{*}{ Variable } & \multicolumn{9}{|c|}{ Percentage of bolls by node positions } \\
\hline & \multicolumn{3}{|c|}{ Nodes 4 to 8} & \multicolumn{3}{|c|}{ Nodes 9 to 12} & \multicolumn{3}{|c|}{ Nodes $>12$} \\
\hline & 2000 & 2001 & 2002 & 2000 & 2001 & 2002 & 2000 & 2001 & 2002 \\
\hline \multicolumn{10}{|c|}{ Nitrogen $\left(\mathrm{kg} \mathrm{ha}^{-1}\right)$} \\
\hline 0 & 10.7 & 4.4 & 6.8 & 43.2 & 28.6 & 29.4 & 46.1 & 67.0 & 63.8 \\
\hline 56 & 22.6 & 8.1 & 12.6 & 45.8 & 40.5 & 43.1 & 31.4 & 51.4 & 44.3 \\
\hline 112 & 28.9 & 19.8 & 34.5 & 41.8 & 48.9 & 41.5 & 29.3 & 31.4 & 23.9 \\
\hline 168 & 32.7 & 24.5 & 37.6 & 42.9 & 49.6 & 36.3 & 24.4 & 25.9 & 26.1 \\
\hline $\operatorname{LSD}(P=.05)$ & \multicolumn{3}{|c|}{7.1} & \multicolumn{3}{|c|}{6.6} & \multicolumn{3}{|c|}{8.6} \\
\hline$P>F$ & \multicolumn{3}{|c|}{$<.01$} & \multicolumn{3}{|c|}{$<.01$} & \multicolumn{3}{|c|}{$<.01$} \\
\hline
\end{tabular}

TABLE 5: Effect of plant population and nitrogen rate on fiber micronaire, strength, length, and uniformity averaged over years.

\begin{tabular}{|c|c|c|c|c|}
\hline Treatment & Micronaire & Strength $\left(\mathrm{kN} \mathrm{kg}^{-1}\right)$ & Length $\left(\mathrm{cm} \mathrm{fiber}^{-1}\right)$ & Uniformity (\%) \\
\hline \multicolumn{5}{|c|}{ Nitrogen $\left(\mathrm{kg} \mathrm{ha}^{-1}\right)$} \\
\hline 0 & 4.03 & 254 & 2.72 & 82.4 \\
\hline 56 & 3.93 & 260 & 2.75 & 82.5 \\
\hline 112 & 3.87 & 259 & 2.75 & 82.1 \\
\hline 168 & 3.89 & 263 & 2.78 & 82.1 \\
\hline $\operatorname{LSD}(P=.05)$ & 0.14 & 5 & 0.03 & ns \\
\hline$P>F$ & .01 & .03 & .01 & .09 \\
\hline
\end{tabular}

Micronaire decreased, and strength and length increased in response to increasing nitrogen, but again the changes were not large enough to invoke discounts. Uniformity was not affected by increasing nitrogen rate.

\section{Conclusions}

Taken together, these data indicate that little can be gained by exceeding populations of 22 plants $\mathrm{m}^{-2}$ or nitrogen rates of $56 \mathrm{~kg} \mathrm{ha}^{-1}$. Plant mortality increased in response to the increase in population density. Stand counts as a percentage of the target population were the highest at 22 plants $\mathrm{m}^{-2}$ at 3 WAP and at harvest indicating a greater economy in seed usage. Yields and boll numbers were equivalent across all populations, and there was little change in fiber properties in response to population or nitrogen rate increases. In addition, the increased height at the higher nitrogen rates may be detrimental to stripper harvesting because a greater stalk biomass would pass through the stripper without achieving greater yield.

\section{Acknowledgment}

The authors wish to thank Ms. Debbie Boykin, Statistician, USDA-ARS, for assistance with the experimental design and data analysis.

\section{References}

[1] S. D. Atwell, R. Perkins, B. Guice, W. Stewart, J. Harden, and T. Odeneal, "Essential steps to successful ultra narrow row on cotton production," in Proceedings of the Beltwide Cotton Conference, pp. 1210-1211, National Cotton Council of America, Nashville, Tenn, USA, January 1996.

[2] M. L. McFarland, R. G. Lemon, F. M. Hons, and T. Gerik, "Nitrogen management in ultra narrow row cotton," in Proceedings of the Beltwide Cotton Conference, pp. 1279-1280, National Cotton Council of America, Orlando, Fla, USA, January 1999.

[3] D. W. Reeves, P. J. Bauer, C. D. Monks, D. P. Delaney, C. H. Burmester, and R. W. Goodman, "Ultra narrow row cotton: tillage, cover crops and nitrogen. Farming systems in ultra narrow rows," in Proceedings of the Beltwide Cotton Conference, p. 623, National Cotton Council of America, San Diego, Calif, USA, January 1998.

[4] M. J. Bader, S. W. Smith, R. Reed, R. McDaniel, L. L. Lanier, and C. Ellis, "UNR farm trials in Georgia 1998," in Proceedings of the Beltwide Cotton Conference, pp. 1482-1484, National Cotton Council of America, Orlando, Fla, USA, January 1999.

[5] N. Cawley, K. Edmisten, R. Wells, and A. Stewart, "Evaluation of ultra narrow row cotton in North Carolina," in Proceedings of the Beltwide Cotton Conference, pp. 558-559, National Cotton Council of America, Orlando, Fla, USA, January 1999.

[6] O. W. Gwathmey and R. M. Hayes, "Ultra narrow row systems of no-till cotton production: research progress in Tennessee," 
in Proceedings of the Southern Conservation Tillage Conference for Sustainable Agriculture, pp. 61-67, Tennessee Agricultural Experiment Station, Jackson, Tenn, USA, July 1996.

[7] P. H. Jost and J. T. Cothren, "Growth and yield comparisons of cotton planted in conventional and ultra-narrow row spacings," Crop Science, vol. 40, no. 2, pp. 430-435, 2000.

[8] P. H. Jost and J. T. Cothren, "Phenotypic alterations and crop maturity differences in ultra-narrow row and conventionally spaced cotton," Crop Science, vol. 41, no. 4, pp. 1150-1159, 2001.

[9] P. J. Wiatrak, D. L. Wright, J. A. Pudelko, B. Kidd, and W. Koziara, "Conventional vs ultra narrow row (UNR) cotton in different tillage systems," in Proceedings of the 21st Annual Southern Conservation Tillage Conference for Sustainable Agriculture, pp. 92-94, Arkansas Agricultural Experiment Station, North Little Rock, Ark, USA, July 1998.

[10] C. W. Bednarz, S. M. Brown, and M. J. Bader, "Ultra narrow row cotton research in Georgia," in Proceedings of the Beltwide Cotton Conference, p. 580, National Cotton Council of America, Orlando, Fla, USA, January 1999.

[11] D. J. Boquet, W. J. Thomas, and R. E. A. Brown, "Nitrogen fertilizer rates and plant density for cotton planted in a 10-inch row spacing," in Proceedings of the Beltwide Cotton Conference, pp. 674-676, National Cotton Council of America, Orlando, Fla, USA, January 1999.

[12] D. J. Boquet, "Cotton in ultra-narrow row spacing: plant density and nitrogen fertilizer rates," Agronomy Journal, vol. 97, no. 1, pp. 279-287, 2005.

[13] E. L. Clawson, J. T. Cothren, and D. C. Blouin, "Nitrogen fertilization and yield of cotton in ultra-narrow and conventional row spacings," Agronomy Journal, vol. 98, no. 1, pp. 72-79, 2006.

[14] M. A. Jones, C. E. Snipes, and G. R. Tupper, "Management systems for transgenic cotton in ultra narrow rows," in Proceedings of the Beltwide Cotton Conference, pp. 714-717, National Cotton Council of America, San Antonio, Tex, USA, January 2000.

[15] J. M. Rinehardt, K. L. Edmisten, R. Wells, and J. C. Faircloth, "Response of ultra-narrow and conventional spaced cotton to variable nitrogen rates," Journal of Plant Nutrition, vol. 27, no. 4, pp. 743-755, 2004.

[16] J. J. Marois, D. L. Wright, P. J. Wiatrak, and M. A. Vargas, "Effect of row width and nitrogen on cotton morphology and canopy microclimate," Crop Science, vol. 44, no. 3, pp. 870 $877,2004$.

[17] D. L. Wright, J. Marois, and P. Wiatrak, "Effect of $\mathrm{N}$ rate and timing, row spacing and Messenger on hard lock and yield of cotton," in Proceedings of the Beltwide Cotton Conference, pp. 596-598, National Cotton Council of America, Anaheim, Calif, USA, January 2001.

[18] J. S. McConnell, R. C. Kirst Jr., R. E. Glover, R. Benson, and W. H. Baker, "Responses to ultra narrow row cotton to nitrogen fertilization," in Proceedings of the Beltwide Cotton Conference, p. 582, National Cotton Council of America, Anaheim, Calif, USA, January 2001.

[19] D. D. Howard, C. O. Gwathmey, and W. M. Percell, "Nitrogen fertilization of ultra narrow row cotton in Tennessee," in Proceedings of the Beltwide Cotton Conference, p. 582, National Cotton Council of America, Anaheim, Calif, USA, January 2001.

[20] C. T. Allen, C. Kennedy, B. Robertson, et al., "Potential of ultra narrow row cotton in southeast Arkansas," in Proceedings of the Beltwide Cotton Conference, pp. 1403-1406, National Cotton Council of America, San Diego, Calif, USA, January 1998.
[21] K. N. Reddy, "Broadleaf weed control in ultra narrow row bromoxynil-resistant cotton (Gossypium hirsutum)," Weed Technology, vol. 15, pp. 497-504, 2001.

[22] W. T. Molin, D. Boykin, J. A. Hugie, H. H. Ratnayaka, and T. M. Sterling, "Spurred anoda (Anoda cristata) interference in wide row and ultra narrow row cotton," Weed Science, vol. 54, no. 4, pp. 651-657, 2006.

[23] J. A. Larson, C. O. Gwathmey, R. K. Roberts, and R. M. Hayes, "Effects of plant population density on net revenues from ultra-narrow-row cotton," Journal of Cotton Science, vol. 8, no. 2, pp. 69-82, 2004.

[24] T. J. Gerik, R. G. Lemon, K. L. Faver, T. A. Hoelewyn, and M. Jungman, "Performance of ultra-narrow row cotton in central Texas," in Proceedings of the Beltwide Cotton Conference, P. Dugger and D. Richter, Eds., pp. 1406-1409, National Cotton Council of America, San Diego, Calif, USA, January 1998. 